\title{
A NOVA TITULAR, PROFESSORA ODETE MEDAUAR, PROFERE SEU DISCURSO DE POSSE
}

Excelentíssimo Senhor Diretor desta Faculdade de Direito, Professor Antonio Junqueira de Azevedo,

Senhores integrantes da Egrégia Congregação,

Senhores Professores,

Senhoras e Senhores.

Expresso, de início, minha satisfação de figurar, ao lado dos professores Luiz Olavo Baptista, Fábio Maria De-Mattia e Álvaro Villaça Azevedo, nesta sessão solene para recepção de novos professores titulares, tradicional nesta Escola.

Sinto-me igualmente honrada por receber a saudação do Professor Celso Lafer, figura ímpar que todos admiram, a quem agradeço os conceitos generosos que me atribuiu.

Um dos pontos comuns aos quatro professores titulares hoje recepcionados solenemente, situa-se no fato de ocuparem cargos novos, cargos decorrentes de novos claros, surgidos e suscitados para esta Faculdade em virtude do empenho do seu atual diretor, professor Antonio Junqueira de Azevedo, a quem expresso meu agradecimento.

Assumir um cargo novo, sem antecessor, para mim assume significação emblemática Simboliza, em termos científicos e também pessoais, o "olhar para frente" a busca de sintonizar as linhas nucleares do Direito Administrativo à época presente e se possível captar tendências futuras, para compatibilizá-lo à intensa dinâmica da sociedade nestas vésperas de um novo século e um novo milênio. E no Brasil, sem dúvida, torna-se crucial a mudança na atuação das estruturas administrativas públicas, para as quais o Direito Administrativo deverá estar preparado, oferecendo soluções e mecanismos afinados com a época presente e com as aspirações da população como um todo. Esta a tônica, que venho tentando imprimir, nos últimos anos, ao estudo, pesquisa e ensino desta disciplina.

Mas não me deterei em considerações sobre temas jurídicos, nem oferecerei profissão de fé retumbante. 
Para alçar ao cargo de Professor Titular nesta Faculdade, passei, como todos, por uma série de fases da carreira acadêmica, expressas na elaboração e defesa de teses, na participação em concurso de ingresso e, no meu caso, em dois concursos para Professor Titular. Todos esses momentos envolveram aflições e angústias, por vezes só compreendidas por aqueles que viveram tais situações. Percorrer esses degraus, já em si, representa profissão de fé.

Mas, hoje, as aflições e angústias se apagam. Permanece o sentimento de realização. O momento é de emoções positivas, de felicidade. Prefiro, então, sintonizar na alegria. Que vai além da conotação profissional. Isso porque a Faculdade, para todos nós, não é só profissão. Desde que aqui pisamos como alunos somos envolvidos pelo seu fascínio. A Faculdade é pessoal; a Faculdade para todos nós é emoção e esta alegria decorre também da forte integração à Faculdade que o momento soleniza.

Não poderiam faltar os agradecimentos. A todos que estiveram solidários comigo, professores, funcionários (aos quais dedico grande estima), aos amigos, alunos, ora num abraço, ora num olhar, ora numa palavra, ora nos votos; impossível nomear todos, mas a lembrança em mim é muito viva.

Peço permissão aos que aqui se encontram para personalizar.

No decorrer das duas décadas da minha carreira nesta Faculdade, dois professores e amigos tiveram presença marcante, não só pelos ensinamentos científicos, mas também pelo rico convívio humano. São os professores Manoel Gonçalves Ferreira Filho e José Afonso da Silva, aos quais dirijo meus agradecimentos e minha homenagem.

À minha mãe Ivone, que por estar doente aqui não se encontra, minha gratidão emocionada, pelo grande amor que me dedicou e que, na sua maneira simples de ser, reuniu a bondade, a pureza de alma, a beleza interior e exterior, a alegria de viver, que sempre teve, apesar das adversidades.

E à minha família aqui presente. Minha irmã Emília, meu irmão Emílio, minha cunhada Sandra, meus sobrinhos Cassius, Caio, Emiliana, Denise e Flávia e Dona Cacilda pelo total apoio, total solidariedade, a tolerância para com os meus defeitos, o compartilhar dos momentos dificeis, a esplêndida alegria e felicidade da nossa convivência familiar, num círculo de afeto e carinho que, jamais, nada quebrará. Os meus agradecimentos e a minha expressão de profundo amor. 